\title{
Revisiting The People and the Court
}

\author{
Harry H. Wellington $\dagger$
}

I.

Charles Lund Black at 70 has earned his reputation: He is unquestionably among a handful whose scholarship occupies prominence in the library of the law's queen subject. During the past three decades, there have been few constitutional lawyers who have written as provocatively - and none as poetically-as Charles. To attend to his writing is to see public law afresh. No one can read him, for example, on the death penalty, ${ }^{1}$ impeachment, ${ }^{2}$ segregation ${ }^{3}$ or state action ${ }^{4}$ without gaining new perspectives on our political morality. And, after a few hours with Structure and Relationship in Constitutional Law, ${ }^{\mathbf{B}}$ one is bound to understand better the essence of our system of government.

Yet, it is my impression that Charles's book on judicial review (the queen topic of the queen subject) is sometimes cited primarily because it was written by an important scholar, with little reference to, or understanding of, its central insights. The book's teaching, about the well established practice of subjecting governmental action to constitutional examination in the courts, often is neglected. I have just discovered that this is a terrible oversight. The People and the Court ${ }^{6}$ would be an important book no matter what its pedigree-the artistic worth of The Man With the Golden Helmet does not depend on its attribution to Rembrandt. Still, it is true that no one but Charles Black could have written his book on judicial review.

II.

I read The People and the Court when it was published, but I did not pay much attention to it. I was a new teacher trying to learn enough labor law and contracts to keep a day or two ahead of my students. I had come to Yale from a clerkship with Felix Frankfurter. There were many new

$\dagger$ Sterling Professor of Law, Yale University.

1. C. Black, Capital Punishment: The Inevitability of Caprice and Mistake (2d ed., augmented) (1974).

2. C. Bl.ACK, IMPEACHMENT: A HANDBOOK (1974).

3. Black, The Lawfulness of the Segregation Decisions, 69 YALE L.J. 421 (1960).

4. Black, The Supreme Court, 1966 Term-Forward: "State Action," Equal Protection, and California's Proposition 14, 81 HaRv. L. Rev. 69 (1967).

5. C. Bi.Ack, Structure and Relationship IN Constitutional LAW (1969).

6. C. Bi.Ack, The People and the CoURt (1960). 
teachers in New Haven that year. Charles, too, was new to Yale; he had come from Columbia as the Henry R. Luce Professor of Jurisprudence. The book he was working on and published shortly thereafter struck me then as a wrong-headed attack on my judge. This, plus my desire to keep afloat, predisposed me to maintain a closed mind. Parenthetically, that is a useful trick for anyone who wants to make intellectual progress along a different front.

This closed-minded approach of mine, however, was not easily maintained. My wife and I had become friends of Charles and Barbara Black, and Sheila Wellington had read the book for its author in its penultimate draft. She liked it, thought it important, and so advised me. Moreover, Charles was a natural at the craft I hoped to master. He was then-and, of course, still is-a fine teacher, a gorgeous writer, and a lawyer who was centrally involved in fighting race discrimination, that enduring issue of our time. Charles also had a young family; he shared the many problems of a large junior faculty that is now small and very senior. Accordingly, it was difficult indeed for me to slight The People and the Court, but I managed.

III.

When I revisited the book in December 1985, I was struck with an insight in it that has been insufficiently remembered by today's scholars, and by the contemporary relevance of arguments that Charles deploys in his defense of judicial review. The insight and the arguments pull together, making a powerful case for the practice established in Marbury $v$. Madison. ${ }^{7}$

Once observed, the insight is almost obvious. It is a strong justification for judicial review:

[T] he prime and most necessary function of the Court has been that of validation, not that of invalidation. What a government of limited powers needs, at the beginning and forever, is some means of satisfying the people that it has taken all steps humanly possible to stay within its powers. That is the condition of its legitimacy, and its legitimacy, in the long run, is the condition of its life. And the Court, through its history, has acted as the legitimator of the government. ${ }^{8}$

Moreover,

[t]he power to validate is the power to invalidate. If the Court were

7. 5 U.S. (1 Cranch) 137 (1803).

8. C. BI.ACK, supra note 6 , at 52 . 
deprived, by any means, of its real and practical power to set bounds to governmental action, or even of public confidence that the Court itself regards this as its duty and will discharge it in a proper case, then it must certainly cease to perform its central function of unlocking the energies of government by stamping governmental actions as legitimate. ${ }^{9}$

Charles's vision of judicial review, his emphasis on its affirmative aspect, should have more significantly influenced the conceptions of American democracy that inform contemporary discussions of constitutional adjudication. What a complex system ours is! Because Congress and the President often test the limits of their constitutional power, and because the minority that questions the legitimacy of such governmental action may be a large fraction of the total population, our democracy requires the use of a disinterested umpire if it is to enjoy tranquility.

For the Court to perform this function, the Constitution must be seen as law and the Court as engaged in adjudication. While constitutional adjudication may require statesmanship, it also requires the training and skill necessary for the interpretation of contracts and statutes. The job of the Court is, then, similar to what courts do at common law and in statutory adjudication. But the legal realists-whatever else they accomplished-have taught all of us who do law in the United States that new law is produced in adjudication. Nor, as Charles tells us, was it ever different; it was merely perceived differently.

This means that when the Court invalidates governmental action-the negative or checking function of judicial review-it makes new law in the way that law is made in adjudication. In hard cases the Constitution is bound to be "open textured," its history ambiguous, and all other sources relevant to its elaboration problematic (and what is relevant is, itself, far from clear).

Nor does this reality, which we have learned from the legal realists, mean that the Court should accept the legislative judgment because Congress is electorally accountable. Not only would such deference destroy the affirmative, validating, legitimating work of judicial review (work that is structurally valuable in a government of limited powers), it would misunderstand the relative institutional competence of Court and Congress. For, as Charles sees it, Congress can no more be a fair judge of prohibitions on its power, such as those contained in the First Amendment, than a defendant can be a fair judge in his own case. Moreover, one who advocates acceptance of the Congressional judgment without serious review by the Court on the ground that Congress is electorally accountable and Supreme

9. Id. at 53 . 
Court justices are not, may have forgotten that our democracy vests the power of the sword in a second term President who is no more electorally accountable than the Chief Justice of the United States. This third term prohibition on presidential office may rest on good reason: Perhaps we must protect ourselves from charismatic leaders. Good as that reason may be, however, it is not as compelling as the functional explanations for giving less dangerous power to the Chief Justice and his several associates. What seems clear is that as long as good reasons do exist, Americans cheerfully delegate enormous power to officials who are not electorally accountable; that is a feature of our democracy that anybody who bothers to look will see. ${ }^{10}$

IV.

The People and the Court predates the argument, found in contemporary constitutional scholarship, that insists upon a distinction between "interpretive" and "noninterpretive" judicial review. ${ }^{11}$ Michael Perry puts the distinction this way:

The Supreme Court engages in interpretive review when it ascertains the constitutionality of a given policy choice by reference to one of the value judgments of which the Constitution consists . . . . The effort is to ascertain, as accurately as available historical materials will permit, the character of a value judgment the framers constitutionalized at some point in the past.

The Court engages in noninterpretive review when it makes the determination of constitutionality by reference to a value judgment other than one constitutionalized by the framers. ${ }^{12}$

The point of the interpretive/noninterpretive distinction is to explain the profession's anxiety over the negative aspect of judicial review. Most (all?) declarations of unconstitutionality are the result of noninterpretive review. Accordingly, the Court is making law without any demonstratable support from those great men who produced or who ratified our fundamental Charter two centuries ago.

I have argued that this distinction derives from a particular and incorrect conception of adjudication which "cuts across the grain of our professional training" and "rests upon a flawed understanding . . . of the inter-

10. See Wellington, The Nature of Judicial Review, 91 YALE L.J. 486, 488-497 (1982).

11. "Originalist" and "nonoriginalist" are sometimes substituted for "interpretive" and "noninterpretive."

12. M. Perry, The Constrtution, The Courts, and Human Rights 10-11 (1982). But see Perry, The Authority of the Text, Tradition, and Reason: A Theory of Constitutional "Interpretation," 58 S. CAI.. L. Rev. 551 (1985) (drops use of "interpretive/noninterpretive" vocabulary). 
relationship of governmental institutions."13 The Court in constitutional adjudication, I have argued, does what courts must do when they decide hard cases. Earlier constitutional scholarship did not use, and contemporary scholarship does not need, a distinction that questions the legitimacy of lawmaking through adjudication.

One of the things I had in mind was simply this: Whenever courts adjudicate they are elaborating a text. At common law that text is prior decisional law, read in its contemporary context; in statutory adjudication it is the legislative enactment, read in the light of a contemporary and particular case; and in constitutional adjudication, it is the Constitution itself, read in the light of the structure and relationship of the governing forms prescribed by the document, and the contemporary problem raised by a case or controversy. As far as I know, the universal practice of courts, when engaged in adjudication, is to acknowledge the power of the relevant text. ${ }^{14}$

Most of us who study or practice law in the United States, however, recognize that textual elaboration in hard cases involves making law, for in hard cases texts do not reveal themselves easily. Lawyers disagree profoundly, of course, on the question of how a court should perform this lawmaking function. This much seems clear, however: In hard cases courts make law whether they look only to language (whatever that means); to language and the intention of the founders, legislators or draftsmen (whatever that means); or to other sources as well (whatever they are). The problematic nature of language, history, structure, and morals is what makes hard cases hard.

During the last decade, some legal theorists have invented a vocabulary that is at odds with the universal judicial practice of paying deference to text. These theorists claim that in constitutional adjudication of human rights questions the Court is not involved in interpretation. Although the use of the word "noninterpretive" in this context is not wrong-one can define "textual elaboration" in a variety of ways-intellectual honesty does not require this new vocabulary. Charles Black's discussion of legal realism should reassure us that the contemporary American lawyer has a realistic and, therefore, generous conception of textual elaboration. Moreover, the new vocabulary misleads the layperson: It invites her to believe that the judicial protection of human rights is a task different in kind from

13. Wellington, History and Morals in Constitutional Adjudication (Book Review), 97 HARv. L. Rrv. 326, 327 (1983).

14. Charles Black has said: "The question is not whether the text shall be respected, but rather how one goes about respecting a text of that high generality and consequent ambiguity which marks so many crucial constitutional texts." C. BLACK, supra note 5 , at 30 . 
what courts do when they decide other types of hard cases. ${ }^{15}$ It most emphatically is not.

Furthermore, while a realistic view of adjudication recognizes the fact that judges make law in hard cases, it need not accept the notion that, when making law, judges are to promote their own beliefs and ideals rather than ours. ${ }^{18}$ Courts do, after all, perform a public, not a private, function. There is therefore no reason why judicial law-making should be seen as subjective in any strong sense. One should-but many do not-distinguish between a generous and a subjective conception of textual elaboration.

In my earlier writings, I would have had more to say on these points if I had better understood The People and the Court. Charles's description of realist teaching helps explain the mistake of embracing an interpretive/ noninterpretive vocabulary in adjudication, while his conception of the legitimating work of judicial review is profoundly important in understanding the interrelationship of governmental institutions in our democracy.

V.

The People and the Court clears away the underbrush. It tells constitutional theorists what direction they should take if they are to make progress. Because judicial review is structurally desirable in a democracy where the federal legislature has limited power, and because judges make law, we need to understand better what should count as sources of law in adjudication. ${ }^{17}$ Charles Black has made it unnecessary for theorists to worry further about the legitimacy of judicial review. If he had done noth-

15. But see Grey, The Constitution as Scripture, 37 Stan. L. REv. 1, 4-5 (1984) (argues that failure to use new vocabulary "itself is bound to mislead").

16. See Wellington, Common Law Rules and Constitutional Double Standards: Some Notes on Adjudication, 83 YALE L.J. 221, 244 (1973) (court is required to assert "our" moral views, not its own).

17. Many contemporary writers of constitutional theory address questions about sources of law by developing conceptions of interpretation. Often these conceptions pay little attention to the rich context in which constitutional adjudication takes place. See, e.g., Perry, supra note 12 . How lawyers argue cases, for example, may influence the way judges interpret texts, and generally lawyers are more interested in winning than in establishing a correct moral principle. Lawyers and law professors, of course, know about this context (and they know too about standing, the case/controversy requirement, etc.); moral philosophers and literary critics may not. They may not even know that in order to obtain a majority, a judge may have to modify the language and scope of her opinion. Indeed, moral philosophers and literary critics may not know that majority opinions are sometimes desperately negotiated documents. See D. O'BRIEN, STORM CENTER 240-62 (1986) ("In order to accommodate the views of others, the author of an opinion for the Court must negotiate language and bargain over substance," id. at 257-58). How wonderful it must feel to be so free.

While I doubt that an acontextual approach will help us in our quest to understand better constitutional adjudication, I appreciate the urge to break problems down into seemingly more manageable parts. I assume, however, that the next phase of the new scholarship will be to apply (and inescapably to modify) freshly minted conceptions in the disorderly context of constitutional adjudication, a context well understood by Charles Black. 
ing else-and, of course, he has done so much more-this would have been a remarkable achievement.

Those of us who work in the territory that Charles has cleared and who worry about the tyranny of the majority may find in Charles more than a natural; if we look, we may discover an intellectual leader. 
HeinOnline -- 95 Yale L.J. 1572 1985-1986 


\section{Published Works of Charles L. Black, Jr.}

\section{BoOKS AND MONOGRAPHS*}

The Humane Imacinatton (Woodbridge, Conn.: Ox Bow Press, 1986).

The: Humane Imagination in the Great Society (Austin: Texas Committee for the Humanities, 1984), reprinted in C. Bl.Ack, The Humane Imagination 1 (1986).

The: Wakinc; Passencier (poetry) (New Orleans: New Orleans Poetry Journal Press Books, 1983).

Drisiston Accordinc; To LaW (New York: Norton, 1981).

Captial. Punishment: The: Inevirability of Caprice and Mistake (2d ed., augmented) (New York: Norton, 1981).

Owis Bay in Babyion (poetry) (Paradise, Cal.: Dustbooks, 1980).

LAW AS AN ART (Knoxville: University of Tennessee College of Law, 1978), reprinted in YALE LAW Rtipor'T, Winter 1979-1980, at 8, and in C. Black, The Humane Imagination 17 (1986).

The Tidfs of Power: Conversations on the American Constitution Between Bob Eckhardt and Charles L. Black, JR. (with B. Eckhardt) (New Haven: Yale Univ. Press, 1976).

The Law of Admirality (with G. Gilmore) (2d ed.) (New York: The Foundation Press, 1975).

Captial. Punishment: The Inevitability of Caprice and Mistake (1st ed.) (New York: Norton, 1974).

IMPEAC:HMENT: $\Lambda$ HANDBOOK (New Haven: Yale Univ. Press, 1974).

The Unfinished Business of the Warren Court (Washington: The Office of the Permanent Committee for the Oliver Wendell Holmes Devise, Library of Congress, 1970), also printed in 46 WASH. L. REv. 3 (1970).

Persphecitives in Constrtutronal. Law (2d ed., revised) (Englewood Cliffs, N.J.: Prentice Hall, 1970).

Structrurf: ANd Rhi.ATtonship in Constitutional Law (Baton Rouge: Louisiana St. Univ. Press, 1969) (republished by Woodbridge, Conn.: Ox Box Press, 1985).

Persprectives in Constrtutional. Law (1st ed.) (Englewood Cliffs, N.J.: Prentice Hall, 1963).

TeI.Fs(X)PES AND Ist.AndS (poetry) (Denver: Alan Swallow, 1963) (republished by New York: AMS Press, 1975).

The Occiasions of Justick: Essays Mostly on Law (New York: Macmillan, 1963).

Thy: Prople: and the Court: Judicial Review in a Democracy (New York: Macmillan, 1960) (republished by Westport, Conn.: Greenwood Press, 1977).

The Law of Admiraity (with G. Gilmore) (1st ed.) (Brooklyn: The Foundation Press, 1957).

Pfrciy Bysshe: Shet.ley as a Translator of Verse (Master's Thesis) (Austin: University of Texas, 1938).

* All items except poems are listed in reverse chronological order within each section. Where there is a significant difference between the dates of delivery and publication, speeches are listed according to the date of delivery, with publication information appended thereto. 


\section{ARticles, Essays, Speeches and Tributes}

Further Reflections on the Constitutional Justice of Livelihood, 86 CoLvM. L. REv. (forthcoming Oct. 1986).

On Reading and Using the Ninth Amendment, in Power and Policy in Quest of Law: Essays IN HoNOR of Eugene Vicror Rostow 187 (M. McDougal \& W. Reisman, eds.) (Dordrecht, Netherlands: Martinus Nijhoff Publishers, 1985; distributed in U.S. by Hingham, Mass.: Kluwer Academic Publishers), reprinted in C. Black, The Humane Imaginatron 186 (1986)

What Teaching and Writing on Admiralty Have Meant to Me, 16 J. Maritime L. \& Commrarce 303 (1985).

Arthur Leff and His Law Dictionary, 94 YALE L.J. 1845 (1985).

The Death Penalty: A National Question, 18 U.C.D. L. REv. 867 (1985).

On Worrying About the Constitution, 55 U. Colo. L. REV. 469 (1984), reprinted in C. BLACK, THE HUMANE: IMAgination 118 (1986).

Remarks at Memorial for Grant Gilmore (Oct. 3, 1982), Yale LAw Report, Fall/Winter 1982-83, at 8 .

Trends in American Constitutional Interpretation, prepared for delivery in Ireland in the Summer of 1981, printed in C. Black, The Humane Imagination 167 (1986).

Perspectives on the American Common Market, in Regulation, Federalism, and INTERState Commerce 59 (also participant in discussion at 91-162) (A. Tarlock ed.) (Cambridge, Mass.: Oelgeschlager, Gunn and Hain Pub., Inc., 1981).

Why a Liberal is Going to Vote for a Democratic President, Yale Daily News, Oct. 20, 1980, at 2, col. 1.

Objections to S. 1382, A Bill to Establish Rational Criteria for the Imposition of Capital Punishment, 26 Crimf and Delinguency 441 (1980).

Caprice and Racism in the Death Penalty, in The Penalty of Death 21 (Final Report of the Annual Chief Justice Earl Warren Conference on Advocacy in the United States, 1980) (Washington: Roscoe Pound-American Trial Lawyers Foundation, 1980).

The Meaning of Article $V$, in The Constitution and the Budget: Are Constitutional LimIts on Tax, Spending and Budget Powers Desirable at the Federal Level? 10 (also participant in discussion at 28-42) (W. Moore \& R. Penner eds.) (Washington: American Enterprise Institute for Public Policy Research, 1980).

Law as an Art, YAl.E LAw REPORT, Winter 1979-80, at 8, originally published as C. BlACK, LAw as AN ART (1978), reprinted in C. Black, The Humane Imagination 17 (1986).

National Lawmaking by Initiative? Let's Think Twice, Human Rights, Fall 1979, at 28, reprinted in C. Bi.ack, The Humane Imagination 106 (1986).

My World With Louis Armstrong, 69 Yale Review 145 (1979), reprinted in 95 Yale L.J. 1595 (1986), and in C. Black, The Humane Imagination 66 (1986).

Amendment by National Constitutional Convention: A Letter to a Senator, 32 OKLA. L. REv. 626 (1979).

Governors' Dilemma, Thr. Nrw Republic, Apr. 28, 1979, at 12.

Reflections on Opposing the Penalty of Death, 10 ST. MARY'S L.J. 1 (1978), reprinted in CRIMINAL Difr.nse, Sept.-Oct. 1978, at 5.

Foreword: The Myth and Reality of Federalism, 9 U. Tol. L. Rev. 615 (1978).

Grant Gilmore as a Friend, 87 YALE L.J. 903 (1978).

Correspondence: On Article 1, Section 7, Clause 3-and the Amendment of the Constitution, 87 YAL.E: L.J. 896 (1978). 
Charles L. Black, Jr.

Reflections on Reading and Using the Constitutional Work of Max Gluckman, in CRossExaminations: Essays in Mrmory of Max Gluckman 1 (P. Gulliver ed.) (Leiden, The Netherlands: E.J. Brill, 1978), reprinted in C. Black, The Humane Imagination 74 (1986).

Introduction to G. Gilmork, ThE. Drath of Contracr (Japanese edition, published through Ohio State Univ. Press, 1978).

Tribute to Grant Gilmore (delivered Apr. 14, 1978), Yale Law Report, Spring 1978, at 5.

Toward a Judicial Role for the Twenty-First Century, 52 WASH. L. REv. 791 (1977).

The Faithless Ellector: A Contracts Problem, 38 LA. L. REv. 31 (1977), reprinted in C. BLACK, ThE Human: Imagina'ton 163 (1986).

Due Process for Death: Jurek v. Texas and Companion Cases, 26 CATH. U.L. REv. 1 (1976).

The Third Century of the American Republic, delivered at The Hague, July 4, 1976, printed in 122 Conc: RrC. 27561 (1976) (appended to remarks of Rep. Pickle), reprinted in C. BLACK, THE Humane Imagination 96 (1986).

Civil Rights in Times of Economic Stress-Jurisprudential and Philosophic Aspects, 1976 U. ILL. L.F. 559, reprinted as Jurisprudential and Philosophic Aspects of Racial Discrimination in Fimployment, in Civil. Liber ries and Civil Rights 57 (V. Stone ed.) (Urbana, Ill.: Univ. of Illinois Press, 1977).

Some Thoughts on the Veto, 40 LAw \& CONTEMP. PROBS. 87 (1976), reprinted in 122 Cong. REC. $2190,2446,2722$ (1976) (appended to remarks of Rep. Drinan).

Talismanic Names and Modern Justice, delivered at Boston University, June 1, 1975, printed in C. Bi.ack, Thr. Humane. Imagination 50 (1986).

The Presidency and Congress, 32 WASH. \& LeE L. Rev. 841 (1975).

Should we abolish the death penalty?, The Sunday Record (Bergen County, N.J.), Apr. 20, 1975, at D1, col. 1, excerpted from C. Bi.ack, Capital Punishment: The Inevitability of CaPRIC: AND Mistake: (1974).

Marital and Physician Privileges-A Reprint of a Letter to a Congressman, 1975 DukE L.J. 45, originally printed in Hearings on Rules of Evidence Before the Special Subcomm. on Reform of Federal Criminal Laws of the House Comm. on the Judiciary, 93d Cong., 1st Sess., Ser. 2, at 240 (1973), reprinted as On the Proposed Federal Rules of Evidence, YALE LAW REPORT, Spring 1973, at 19.

Alexander Mordecai Bickel, 84 Yal.e L.J. 199 (1974).

An Impression of the Late Chief Justice, 88 Harv. L. REv. 6 (1974).

The Working Balance of the American Political Departments, 1 Hastings ConsT. L.Q. 13 (1974).

The National Court of Appeals: An Unwise Proposal, 83 YAL.E L.J. 883 (1974).

Constitutionality of the Eickhardt Open Beaches Bill, 74 ColuM. L. REv. 439 (1974).

Why the Senate Shouldn't Get the Tapes, Los Angeles Times, Aug. 5, 1973, § 9, at 1, col. 5.

Mr. Nixon, the Tapes, and Common Sense, New York Times, Aug. 3, 1973, at 31, col. 1.

The Bremen, COGSA and the Problem of Conflicting Interpretation, 6 VAND. J. Of Transnat'L LAW 365 (1973).

On the Proposed Federal Rules of Evidence, YALE LAW REPORT, Spring 1973, at 19, originally printed in Hearings on Rules of Evidence Before the Special Subcomm. on Reform of Federal Criminal Laws of the House Comm. on the Judiciary, 93d Cong., 1st Sess., Ser. 2, at 240 (1973), reprinted as Marital and Physician Privileges-A Reprint of a Letter to a Congressman, 1975 Duke. L.J. 45.

Note: Is there Already a British Bill of Rights?, 89 LAw QUAR. REv. 173 (1973).

Amending the Constitution: A Letter to a Congressman, 82 YALE L.J. 189 (1972).

The Crisis in Capital Punishment, 31 MD. L. Rev. 289 (1971). 
Is the State of Georgia in the Fifth Circuit?, 81 YALE L.J. 30 (1971), reprinted in YALE LAW Rr:Pok'r, Spring 1972, at 11.

"Comment" on Cruse, The Historical Roots of American Social Change and Social Theory, in Is Law Dran? 332 (E. Rostow ed.) (New York: Simon \& Schuster, 1971).

The Unfinished Business of the Warren Court, 46 WASH. L. REv. 3 (1970), reprinted and separately published as C. Bl.ACK, The UNFINISHed Business of THE WARREN Court (1970), reprinted in part as On the Failure and Success of Courts, in C. Black, The Humane IMAGINATION 140 (1986).

A Note on Senatorial Consideration of Supreme Court Nominees, 79 YAlE L.J. 657 (1970).

Some Notes on Law Schools in the Present Day, 9 VENruRes 69 (1969), reprinted in 79 YALE L.J. 505 (1970).

Law and Developing Social Problems, 47 F.R.D. 406 (1968), reprinted in The Legal Intelligencer, Sept. 25, 1968, at 1, col. 1 .

Representation in Law and Equity, in Nomos X: RePresentation 131 (J.R. Pennock \& J. Chapman eds.) (New York: Atherton Press, 1968).

Untitled essay (on "What can a lawyer do about racism?") in Symposium in Memory of Dr. Martin Luther King, Jr., 68 Colum. L. Rev. 1011, 1014 (1968).

The Supreme Court, 1966 Term-Foreword: "State Action," Equal Protection, and California's Proposition 14, 81 HARv. L. REv. 69 (1967).

Constitutional Problems in Compulsory "National Service," Yale LAw RePORT, Summer 1967, at 19, reprinted in C. Black, The Humane Imagination 156 (1986).

The Problem of the Compatibility of Civil Disobedience with American Institutions of Government, 43 Trx. L. Rev. 492 (1965).

Religion, "Standing," and the Supreme Court's Role, 13 J. PuB. LAw 459 (1964).

Proposed Constitutional Amendments: They Would Return Us to Confederacy, 49 A.B.A. J. 637 (1963).

The Conservative and the Court: A Bedtime Story, in C. Black, The Occasions of Justice: EsSAYS MOSTLY ON LAW 80 (1963).

The Proposed Amendment of Article V: A Threatened Disaster, 72 Yal. L.J. 957 (1963), reprinted in 109 Cong. REC. 8757 (1963) (appended to remarks of Sen. Douglas).

Inequities in Districting for Congress: Baker v. Carr and Colegrove v. Green, 72 YALE L.J. 13 (1962).

The Constitution and Public Power, 52 Yale Review 54 (1962).

The Law and Civil Rights, Radio Address on "Yale Reports," Station WTIC (Jan. 21, 1962), printed in C. B1.Ack, The Occasions of Justice: Essays Mostly on Law 162 (1963).

Changing (and Unchanging) Faces of Law, 51 Yale Review 35 (1961), reprinted in C. Black, The Occasions of Justice: Essays Mostly on Law 3 (1963).

Mr. Justice Black, the Supreme Court, and the Bill of Rights, HARPER's, Feb. 1961, at 63, reprinted in C. Black, The Occasions of Justice: Essays Mostiy on Law 89 (1963).

The Supreme Court and Democracy, 50 Yale Review 188 (1960), reprinted in C. Black, The. Occiasions of Justice: Essays Mostly on Law 61 (1963), and in The Scientist as an Artist and Others 53 (M. Kitagaki ed.) (Kyoto: Apollon-Sha, 1962).

"Moderation" in the Sixties, Too?, The New Republic, Nov. 21, 1960, at 7.

A Note on the Alexia Case, Monocle, Summer/Fall 1960, at 18 (under pseudonym "Charles Lund"), reprinted in C. Black, The Occasions OF Justice: Essays MOSTLY ON LAw 192 (1963).

The Two Cities of Law, Saturday Evening Post, Apr. 2, 1960, at 32, reprinted in C. Black, The 
Charles L. Black, Jr.

Ocdasions of Justick: Essays Mostly on Law 17 (1963), and in C. Black, The HuMANE: IMACinatton 35 (1986).

The Lawfulness of the Segregation Decisions, 69 YaLe L.J. 421 (1960), reprinted in C. BLACK, The Occasions of Justic:: Essays Mostly on Law 129 (1963), and in Selected Essays on Consitiumonal. LAw, 1938-1962, at 844 (Committee of the Ass'n of Amer. Law Schools cds.) (St. Paul: West Pub. Co., 1963).

Commencement Address, The Storm King School, Cornwall-on-Hudson, N.Y. (June 7, 1958), in C. Bi.ack, Th: Ocxisions of Justice: Essays Mostly on Law 206 (1963), and in G. Bi.ac:K, Thk Humane Imagination 58 (1986).

A Note on Material Progress, The New Republic, Mar. 10, 1958, at 8, reprinted in C. Black, The Occasions of Justice: Essays Mostly on Law 199 (1963).

Old and New Ways in Judicial Review, The Bowdoin College Bulletin, No. 328, Mar. 1958.

Paths to Desegregation, The: New Republic, Oct. 21, 1957, at 10, reprinted in C. Black, The Occiasions of Justick: Essays Mostly on Law 144 (1963).

He Cannot Choose But Hear: The Plight of the Captive Auditor, 53 Colum. L. Rev. 960 (1953), reprinted in C. Black, The Occasions of Justice: Essays Mostly on LAw 108 (1963).

A Tribute to Jerome Michael, Columbia Law School News, Feb. 20, 1953, at 2, col. 2, reprinted in C. Bi.ack, The: Occiasions of Justice: Essays Mostry on Law 203 (1963).

Counsel of Their Own Choosing, The American Indian, Fall 1951, at 3.

Committee Hearing Reveals Faculty Rigors at Columbia, Columbia Law School News, Mar. 27, 1950, at 4, col. 3 (under the pseudonym "Carlo Neri").

Admiralty Jurisdiction: Critique and Suggestions, 50 CoLuM. L. REv. 259 (1950).

\section{Book Reviews}

A Round Trip to Eire: Two Books on the Irish Constitution, 91 YAlE L.J. 391 (1981) (reviewing J. O'Rtill.l.y \& M. Redmond, Cases and Materials on the Irish Constitution (1980) and J. KEI.I.Y, THE: IRISH ConstituTION (1980)).

A Constitutional Question, New York Times, Jan. 8, 1978, Sec. VII (Book Review), at 13, col. 1 (reviewing M. Marcus, Truman and the Steel Seizure Case: The Limits of PresiDENIIAI. Power (1977)).

New York Times, Feb. 29, 1976, Sec. VII (Book Review), at 23, col. 1 (reviewing A. Cox, ThE Rol.: of THE: SUPREME: CoURT IN AMERICAN Government (1976)).

In Pursuit of Union, 53 Yai.z. Review 580 (1964) (reviewing P. Nagel, One Nation Indivisible: Thi: Union in American Thought, 1776-1861 (1964) and C. Rossiter, Alexander Hamil:Ton and the Constrtution (1964)).

60 Cot.um. L. Rkv. 566 (1960) (reviewing J. Greenberg, Race Relations and American Law (1959)), reprinted in C. BLACK, The Occasions of Justice: Essays MostLy on Law 181 (1963).

Dixie-Withdrawal Without Defeat, The New Republic, July 21, 1958, at 19 (reviewing W. Dykrman \& J. Strokfly, Neither Black Nor White (1957) and H. Ashmore, AN EpITAPH FOR DIXIE (1958)), reprinted in C. BLACK, The Occasions of Justice: Essays MOSTIY ON LAW 187 (1963).

Long Road Home, The Progressive, May 1958, at 52 (reviewing J. S. Redding, The Lonesome Road: The Story of the Negro's Part in America (1958)).

The Practice of Forbearance, The New Repubuc, Dec. 30, 1957, at 17 (reviewing W. Berns, FRE:BDOM, VIRTUE AND THE FIRST AMENDMENT (1957)), reprinted as Walter Berns on Freedom and Virtue, in C. BLACK, The Occasions of Justice: EsSays MOSTLy on LAW 102 (1963). 
Constitutional Issues Today, 47 Yal.e Revik:w 117 (1957) (reviewing J.J. Kil.PATRIC:, SoverRian States: Notes of a Crtizen of Virginia (1957) and S. Hook, Common SEnsk: and the: FIFIH AMENDMENT (1957)), reprinted in part as James Jackson Kilpatrick's "The Sovereign States," in C. Bl.ack, The Occiasions of Justice: Essays Mostly on Law 173 (1963).

Judicial Restraint, 46 Yal.F Review 432 (1957) (reviewing S. Konffsky, The Lecic:y of Holmes and Brandeis: A Study IN THE INFLUenc:e of IdEAs (1956) and A.T. MAsON, Hari.an Fiske Stone: Phllar of the Law (1956)), reprinted in C. Black, The OcccaSions of Justick: Essays MOSTLy on Law 78 (1963).

55 Col.um. L. Rkv. 766 (1955) (reviewing E.A. Hokbei., Thr: Law of Primttive: Man: $\Lambda$ StudY in Comparative legal. Dynamics (1954)), reprinted in C. Black, The Occasions of Jusitick: Essays Mostly on Law 45 (1963).

55 Col.um. L. Rev. 249 (1955) (reviewing M. Cohen, American Thought-A Critical. Skerch (1954)), reprinted in C. Black, The OCciasions of Justice: Essays Mostl.y on Law 32 (1963).

3 J. Legal. Enuc. 496 (1951) (reviewing. G. Sprague \& N. Healy, Cases on the Law of admiRAI:IY (1950)).

60 YaI.E L.J. 380 (1951) (reviewing A. Nussbaum, Money in the Law: Nationai. ANd INTERNationai. (1950)), reprinted in C. Black, The OCcastons of Justice: Essays Mostly ON LAW 51 (1963).

36 Cornil.1. L.Q. 417 (1951) (reviewing P. Meinhardt, Inventions, Patents, and Monopoly (2d ed. 1950)).

23 Tul. L. Rkv. 426 (1949) (reviewing B. TER HAAR, AdAT LAW in INDONESia (1948)).

47 Col.um. L. Rrv. 1250 (1947) (reviewing H. Gutteridge, Comparative Law (1946)), teprinted in C. Bl.ack, The Occasions of Justice: Essays Mostly on LAW 40 (1963).

\section{INTERVIEWS}

The President and the Rule of Law: The Steel Seizure Case; An Interview with Charles L. Black, $J r$, in The: Supreme Court and Human Rights 17 (Voice of America Forum transcript, B. Marshall ed.) (Washington: Voice of America, 1982).

An Interview with Charles Black (on the death penalty), in CRIMINal DefEnSE, May/June 1980, at 13.

Television Interview concerning the impeachment process, on Meet the Press, National Broadcasting Company, July 28, 1974, published as Meet the Press, vol. 18, no. 30 (Washington: Merkle Press Inc., 1974).

\section{Congressional Materials}

Testimony in Amendments to the Congressional Budget and Impoundment Control Act of 1974 (Pub. L. 93-344): Hearings Before the Subcommittee on the Rules and Organization of the House of the House Committee on Rules, 95th Cong., 2d Sess. 90 (1978).

Testimony in Extending the Ratification Period for the Proposed Equal Rights Amendment: Hearings on H.J. Res. 638 Before the Subcommittee on Civil and Constitutional Rights of the Committee on the Judiciary, 95th Cong., 1st Sess. 68 (1977).

The Third Century of the American Republic, in 122 Cong. Rec. 27561 (1976) (appended to remarks of Rep. Pickle), reprinted in C. Biack, The Humane Imagination 96 (1986).

Some Thoughts on the Veto, in 122 CoNG. REc. 2190, 2446, 2722 (appended to remarks of Rep. Drinan) (1976), originally printed in 40 LAw \& ConTEMP. ProBs. 87 (1976).

Letter of July 30, 1973 to Congressmen Bob Eckhardt, concerning "obtaining the White House Tapes," in 119 CoNG. Rec. 27438 (1973) (appended to remarks of Rep. Eckhardt). 
Letter of Feb. 5, 1973 to Congressman William L. Hungate, concerning marital and physician privileges in proposed Federal Rules of Evidence, in Hearings on Rules of Evidence Before the Special Subcomm. on Reform of Federal Criminal Laws of the House Comm. on the Judiciary, 93d Cong., 1st Sess., Ser. 2, at 240 (1973), reprinted as On the Proposed Rules of Evidence, YAl.F. LAW REPORT, Spring 1977, at 19, and as Marital and Physician Privileges-A Reprint of a Letter to a Congressman, 1975 DukE L.J. 45.

Letter of Jan. 7, 1963 to Arthur J. Freund, Esq., and reprint of The Proposed Amendment of Article V: A Threatened Disaster, 72 YAle L.J. 957 (1963), in 109 Cong. REC. 8756 (1963) (appended to remarks of Sen. Douglas).

\section{SELECTEd LetTers to the Editor}

Terrorism Killed a 2d American During the Achille Lauro Affair, N.Y. Times; Nov. 1, 1985, at A34, col. 3.

Reagan, Carter and the Future U.S. Supreme Court, N.Y. Times, Oct. 16, 1980, at A30, col. 4.

Weak Case for an 'Open' Democratic Convention, N.Y. Times, July 30, 1980, at A20, col. 3.

If It's Reagan the Democrats Want, N.Y. Times, May 28, 1980, at A22, col. 4.

On the Limits of a Constitutional Convention, N.Y. Times, Sept. 10, 1977, at 24, col. 4.

Implications of the Sirica Ruling: Still a Nightmare, N.Y. Times, Sept. 20, 1973, at 46, col. 3.

Judge Sirica's Ruling and the Presidency, Wash. Post, Sept. 12, 1973, at A23, col. 3.

The Pitfalls of Judge Sirica's Ruling, N.Y. Times, Sept. 6, 1973, at 36, col. 3.

“. . . that the Laws Be Faithfully Executed," N.Y. Times, Apr. 15, 1973, § IV, at 16, col. 4 (on presidential "impoundment" of funds).

Role for Bar Opposed, N.Y. Times, May 25, 1970, at 32, col. 3 (on ABA role in evaluating judicial nominees).

Amendment Favored for Lowering Voting Age, N.Y. Times, Apr. 5, 1970, § IV, at 13, col. 1 (with Alexander M. Bickel, Robert H. Bork, John Hart Èly, Louis H. Pollack \& Eugene V. Rostow).

Objections to Carswell, N.Y. Times, Feb. 17, 1970, at 42, col. 4.

For Voting Rights Act, N.Y. Times, Dec. 7, 1969, § 4, at 11, col. 4.

Call for a National Convention, N.Y. Times, Apr. 2, 1967, § IV, at 11, col. 1.

Role of the Supreme Court, N.Y. Times, Mar. 23, 1958, § IV, at 8, col. 6.

From a Primitive Radical, Dallas Morning News, Aug. 8, 1937, § II, at 6, col. 7.

\section{PoEms**}

For an Animal Lover, The American Bard, vol. 13, No. 6, at 13 (Apr.-June 1957).

Reverie, The American Bard, vol. 13, No. 5, at 35 (Jan.-Apr. 1957).

The Ticket, The ANTIOch Review, vol. 19, No. 2, at 149 (Summer 1959).

Ancient Poet in a Print, The ANTtoch Review, vol. 18, No. 3, at 316 (Fall 1958), reprinted in C. Br.ack, Trlescopes \& IsLands 24 (1963).

The Age of Chivalry, ApProACh, No. 50, at 25 (Winter 1964).

** Those of Professor Black's poems which have been published exclusively in his three volumes of poetry are not listed here. Thus, only poems which have been separately published are included. They are arranged according to an alphabetical listing of the journals in which they appeared. The poems are in reverse chronological order within each separate journal listing. 
King Tacitut, APPROACH, No. 50, at 37 (Winter 1964).

Figureheads, Approac: No. 48, at 38 (Summer 1963), reprinted in C. Bi.Ac:K, Owis Bay in BABYI.ON 7 (1980).

India Haven, Approach, No. 47, at 37 (Spring 1963), reprinted in C. BlACK, OWIs BAY IN BABYI.ON 64 (1963).

Missed Occasion, Approac:, No. 41, at 10 (Fall 1961), reprinted in C. Black, ThE Wakinc; PASSENGir 30 (1983).

Geology Revisited, APpROACH, No. 41, at 12 (Fall 1961).

Aspects, ApproACH, No. 36, at 23 (Summer 1960), reprinted in C. Bl.ACK, Tri.bscopes \& Isl.ANDS 47 (1963).

Old Woman Serving Food behind a Counter, APPROACH, No. 36, at 24 (Summer 1960), reprinted in C. Bi.Ack, Tri.rscopes \& IsL.Ands 30 (1963).

The Reliquary, $\Lambda$ PPROACH, No. 29, at 19 (Fall 1958).

North Shore Song, APPROACH, No..29, at 19 (Fall 1958).

Cases and Points, Appronc:H, No. 29, at 20 (Fall 1958).

Priest of Sun-in-the-Water, Appronch, No. 29, at 21 (Fall 1958).

After a Digest Paragraph, ApProAch, No. 24, at 13 (Summer 1957), reprinted in C. B..Acк, THi.fsc:opes \& IsI.ANDS 22 (1963).

Gems and Spells, Arizona QuAr'Terly, vol. 36, No. 2, at 164 (Summer 1980).

The Reach of Silence, ARIzona QuAR'teriy, vol. 35, No. 4, at 372 (Winter 1979), reprinted in C. Bi.ac:k, The: Waking; Passenger 29 (1983).

All Too Little on Pictures, Arizona Quarterly, vol. 35, No. 2, at 169 (Summer 1979).

On the World's Being Perpetually Renewed, Arizona Quarterly, vol. 32, No. 4, at 366 (Winter 1976), reprinted in C. Black, The. Waking Passenger 44 (1983).

Reciprocation, ARIzoNA QUARTFRI.Y, vol. 30, No. 2, at 141, reprinted in C. BLACK, OWI.S BAY IN BABYL.ON 22 (1980).

The Imagination of Adam, ARIzona QuARterly, vol. 29, No. 1, at 25 (Spring 1973).

My Daughter is Too Smart for Me Anymore, ARIzona Quarterly, vol. 28, No. 2, at 173 (Summer 1972).

Another Century, Arizona QUARTERLy, vol. 27, No. 1, at 52 (Spring 1971).

The Phrjgian Cup, Arizona Quarterly, vol. 25, No. 1, at 17 (Spring 1969), reprinted in C. Bi.Ac:k, OWIS BAy IN BABYLION 63 (1980).

Signs, ARIzona Quartert.y, vol. 22, No. 1, at 26 (Spring 1966).

Remainders, ArIzona QuARTERly, vol. 14, No. 1, at 60 (Spring 1958).

The Burning of a Temple, ART and Social. Experience, vol. 12, No. 2, at $283^{\text {"Summer/Fall }}$ 1975), reprinted in C. Black, OWLS Bay IN Babylon 10 (1980).

The Fireplace, $\Lambda$ R'T AND Social EXPERIENCE, vol. 12, No. 2, at 284 (Summer/Fall 1975), reprinted in C. Bi.ack, OWLS BAy In Babylon 11 (1980).

My Daughter Asks Relief From Monotony of Response, The Briort Poetry Journal, vol. 22, No. 3, at 16 (Spring 1972), reprinted in C. Black, The Waking Passenger 49 (1983).

Swimming, Thk Bl.uk River Poetry Magazine, vol. 25, No. 92, at "4" (unpaginated) (Summer 1956).

Chinese Imitations, The Bl.uk: Rivkr Pokrry Magazine, vol. 25, No. 92, at "4" (unpaginated) (Summer 1956).

The Letter, Boston Universiry Journal, vol. 20, No. 3, at 43 (Autumn 1972), reprinted in C. Bi.ac:k, OWis Bay in Babylon 15 (1980). 
Charles L. Black, Jr.

Disappeatance, in Caravan "Scout" Supplement (undated and unpaginated).

Toward a Biography, Cari.r:Ton Miscel.tany, vol. 4, No. 3, at 72 (Summer 1963).

A Lady in Sorrow, Cari.tron Miscelllany, vol. 4, No. 3, at 73 (Summer 1963), reprinted in C. Bi.ac:k, OWis BAy in Babylon 8 (1980).

High Stone Walls Past Trenton, Carlezron Miscellany, vol. 3, No. 4, at 13 (Fall 1962), reprinted in C. Bi.Ac:K, OWLS BAy IN BABYLon 60 (1980).

Lines at the City Limits, Cari.fton Miscellany, vol. 3, No. 2, at 14 (Fall 1962).

Scientific Obsetuation, Carleton Miscellany, vol. 3, No. 2, at 9 (Spring 1962).

The Solitary, The: Carol.ina Quarterly, vol. 10, No. 1, at 66 (Fall 1957).

'Bye, 'Bye Colored Bird, Chicago Review, vol. 10, No. 2, at 64 (Summer 1956).

Checking Gavin at nine o'clock, Christian Science Monitor, Feb. 19, 1982, at 21, col. 1.

He attains an outer room, Christian Science Monitor, Jan. 24, 1978, at 17, col. 3.

Waiting, The Christian Science Monitor, Dec. 20, 1977, at 21, col. 2.

Desert, The Christian Science Monitor, Sept. 30, 1977, at 28, col. 4.

The Old Man's First Birthday Alone, Colorado-North Review, vol. 15, No. 3, at 31 (Spring 1978), reprinted in C. Black, The Waking Passenger 62 (1983).

The Falling Girl, The, Colorado Quarterly, vol. 26, No. 2 at 20 (Summer 1977).

At the Desk, The Colorado Quarterly, vol. 8, No. 4, at 303 (Spring 1960), reprinted in C. Bl.ack, Thi.fscopes \& Islands 39 (1963).

Songs of Three Women, The Colorado QuarterLy, vol. 7, No. 3, at 317 (Winter 1959), reprinted in C. Bi.acik, Tht.rscopes \& Islands 38 (1963).

The Price, The Colorado Quarterly, vol. 7, No. 3, at 31 (Winter 1959).

Conversation Piece, The Colorado Quarterly, vol. 7, No. 3, at 318 (Winter 1959).

Armistice, The Columbia Review, Fall 1969, at 39, reprinted in C. Black, The Waking PasSENGER 15 (1983).

The Ghost of P.T. Barnum, The Columbia Review, Fall 1969, at 39, reprinted in C. Black, The WAKing PASSEnger 70 (1983).

Music for a Geologist, Dki.ra, No. 51, at 33 (Spring 1973), reprinted in C. Black, The Waking PAssinger 36 (1983).

The Loaded Cloud of Rain, DeltA, No. 48, at 34 (Mar. 1971).

$A$ Note on the Sumarians, Dei.TA, No. 48, at 34 (Mar. 1971).

On Understanding Sarah, Dri.ra, No. 46, at 11 (Winter 1969), reprinted in C. Black, OwLS BAY IN BABYLOON 32 (1980).

The Two Ideas, Dri.TA, No. 45, at 15 (Mar. 1969), reprinted in C. BlaCk, Owls BAy IN BABylon 21 (1980).

She and her Hunter, DelrA, No. 43, at 10 (June 1968).

Deus ex Machina, Delita, No. 41, at 59 (Sept. 1967), reprinted in C. Black, OwLs BAy IN BABYI.ON 26 (1980).

Eilegy, Drinver Quarterly, vol. 17, No. 1, at 102 (Spring 1982).

A Disturbed Vision of Spain, Denver Quarterly, vol. 17, No. 1, at 103 (Spring 1982).

The King Repairs to His Temple, Denver Quarterly, vol. 14, No. 2, at 46 (Summer 1979).

Stone Can Stand, Drifiwoon EAST, vol. 6, No. 1, at 18 (Winter 1978).

Disclaimer, EpOK:H, vol. 8, No. 3, at 171 (Fall 1957).

Distraction, Epos, vol. 9, No. 1, at 22 (Fall 1957), reprinted in Epos ANTHolocy (Lake Como, Fla.: New Athenaeum Press, 1958). 
The Dance of Cold, ThE. Fiddieht.AD, No. 95, at 89 (Fall 1972), reprinted in C. Bl.Ack, OwLS BAY IN BABYL.ON 38 (1980).

Christmas Day, The Findl.EHEAd, No. 95, at 89 (Fall 1972), reprinted in C. Bl.ACK, OWls BAY IN BABYi.ON 43 (1980).

Flight of the Sexton, The. Findlehesd, No. 86, at 77 (Aug.-Oct. 1969).

Robin Desires to Own a Very Small Tornado, The. Findlehead, No. 86, at 77 (Aug.-Oct. 1969), reprinted in C. Bl.Ack, The Waking Passenger 48 (1983).

Prominent Destruction, The Fiddiehtad, No. 79, at 16 (Mar.-Apr. 1969), reprinted in C. Bl.Ac:K, OWis BAY IN BABYion 6 (1980).

Days and Works, The. Find.EHEAd, No. 71, at 60 (Spring 1969).

Be Certain, The Fidd.ehead, No. 69, at 78 (Fall 1966).

Thanks for a Candle, The. Fidnlehead, No. 64, at 24 (Spring 1965).

Summer Lady, ThE: Fidd.eHEAd, No. 64, at 25 (Spring 1965).

Home for Christmas Morning, ThE: FiddleheAd, No. 63, at 68 (Winter 1965), reprinted in C. Bl.Ack, The. Waking Passenger 78 (1983).

The Picture by the Record Cabinet, The Fiddemesd, No. 60, at 61 (Spring 1964).

The Visitor, Thk. Fidd.r.hrad, No. 53, at 55 (Summer 1962).

Bejond Seeing and Hearing, ThE Fiddl.kead, No. 46, at 37 (Autumn 1960).

Road from Oaxaca, The Fiddlekead, No. 46, at 39 (Autumn 1960).

Commentary, ThE Fiddlehtad, No. 42, at 39 (Fall 1959).

New Moon, ThF. Fiddi.kHEAd, No. 40, at 13 (Spring 1959).

The Seafaring Man, ThE Findl.kHEAd, No. 39, at 31 (Winter 1959), reprinted in C. Bl.Ac:k, THI.Fsc:oprs \& Is1.ANDS 33 (1963).

Shang Bronzes, ThE. Findi.rekAd, No. 36, at 22 (Spring 1958).

An Archaism, The Fiddi.thead, No. 34, at 6 (Fall 1957).

An Old Story, Firfi.Ands ARTs Review, 1978, at 41.

Fable, Fot.10, vol. 22, No. 3, at 18 (Summer 1957).

Rohrschach A Bestiary, Fol.Io, vol. 21, No. 3, at 38 (Summer 1956), reprinted in C. BLACK, THI.FSC:OPES \& ISI.ANDS 39 (1963).

The Newer Cities, Grensis Wrst, vol. 2, No. 5, at 60 (Fall 1963), reprinted in C. Bl.ACK, OwLS BAy IN BABYion 54 (1980).

The Lesson, The Grorgia Rrview, vol. 13, No. 1, at 52 (Spring 1959).

Lucretian Fantasy, ThF. Grecour'r Review, vol. 3, No. 1, at 47 (Dec. 1959), reprinted in C. Bi.Ac:K, THL.kscopres \& IsLands 15 (1963).

City of Dreams, Hart.equin, vol. 3, No. 1, at 13 (1959).

When I Left There, Hari.fQuin, vol. 3, No. 1, at 13 (1959), reprinted in C. Black, Telescopes \& Isi.ANns 34 (1963).

Travel Talk, Hari.fiuin, vol. 3, No. 1, at 14 (1959), reprinted in C. Black, Telescopes \& IsI.ANDS 21 (1963).

The Possibility of Children Denied, Hratus, No. 1, at 14 (1970).

Counsel, $\Lambda$ Houyhnhnm's Scrapbook, No. 4, at 8 (Dec. 1958).

"This is Mr. Black. He Has Such Interesting Interests!," A Houyhnhnm's ScrapBook, No. 4, at 9 (Dec. 1958).

To a Standard Air, A Houyhnhnm's ScRAPBook, No. 4, at 9 (Dec. 1958). 
Charles L. Black, Jr.

Offstage Action, ^ Houyhnhmm's Strapbook, No. 3, at 16 (July 1957), reprinted in C. Black, Tri.t.Sc:olps:s \& Ist.ANDS 36 (1963).

Daddy Comes Home, A Houyhnhnm's Scrapbook, No. 2, at 9 (Feb. 1957).

Barrier, A Houyhnhmm's Scrapbook, No. 2, at 9 (Feb. 1957).

Calligraphy, A Houyhnhnm's SCRAPBOOK, No. 2, at 10 (Feb. 1957).

Revision, A Houyhnhnm's Sc:Rapbook, No. 1, at 6 (Autumn 1956/Winter 1957).

Occasion, $\Lambda$ HouYhnhnm's Scrapbook, No. 1, at 7 (Autumn 1956/Winter 1957).

Quandry, A HouyhnhnM's Scrapbook, No. 1, at 7 (Autumn 1956/Winter 1957).

Philosophy I, Inı.AND, vol. 4, No. 3, at 21 (Spring 1962).

Flash Shot, Ini.AND, vol. 3, No. 1, at 34 (Summer 1959).

Reformed Wedding, Ini.AND, vol. 2, No. 3, at 26 (Winter 1959).

Putting the Horn Away, Jropardy, vol. 14, Spring 1978, at 36.

Polarion, LAOMEdon Review, vol. 4, Apr. 1978, at 46.

Reflections, The LIterary Review, vol. 2, No. 4, at 545 (Summer 1959).

Colophon, The Lrterary Review, vol. 2, No. 1, at 108 (Autumn 1958), reprinted in C. Bl.ACk, TEI.ESCOPFS \& ISI.ANDS 48 (1963).

March Snow, The: Ltikrary Revikw, vol. 2, No. 1, at 108 (Autumn 1958).

For E.T.D., at Work on Chaucer's Text, The LrTerary Review, vol. 2, No. 1, at 109 (Autumn 1958).

Wildwood China, Thi Lmtre: Magazine, vol. 14, Nos. 1-2, at 16 (1983).

One of the Scholats, The Little Magazine, vol. 14, Nos. 1-2, at 17 (1983).

Remarks for Law Day, The Little Magazine, vol. 13, Nos. 3-4, at 61 (1982), reprinted in C. Bi.ack, The. Waking Passenger 73 (1983).

A Reminiscence of the Early 'Fifties, The Little Magazine, vol. 11, No. 2, at 20 (Summer 1977). Another Thing About Glossolalia, The Little Magazine, vol, 9, No. 2, at 65 (Spring 1975).

Two Moonfaces, The Litrtle Magazine, vol. 8, Nos. 1-2, at 79 (Spring/Summer 1974).

1000 Words, The. LitTle Magazine, vol. 7, No. 3, at 32 (Fall 1973), reprinted in C. Black, The Waking: Passenger 59 (1983).

Old is the Dallas Blues, The. Littre Magazine, vol. 7, No. 3, at 32 (Fall 1973).

The Fief of the Conde de Bexar, The Little Magazine, vol. 6, No. 4, at 27 (Winter 1973).

Balance to Salt, The LITTLE Magazine, vol. 6, No. 4, at 28 (Winter 1973), reprinted in C. Black, The. WAKing PASSENger 72 (1983).

The French Harpsichordist, The LitTle Magazine, vol. 5, No. 2, at 55 (Summer 1971), reprinted in C. Bi.ack, The. Waking Passenger (1983).

A Far Northern Mention of Pandemic Aphrodite, The Lrrmle Magazine, vol. 4, No. 2, at 31 (Summer 1970), reprinted in C. Black, OwLs BAy in BAByLon 48 (1980).

The Defeated Boat, The LitTle Magazine, vol. 4, No. 2, at 32 (Summer 1970), reprinted in C. Bi.ack, OWI.s BAy IN BABYLon 39 (1980).

Loki Returns or Remains, The Little Magazine, vol. 4, No. 1, at 21 (Spring 1970).

Finger Exercise, The Mischllanfous Man, No. 15, at 27 (Spring 1959).

A Useful Citizen, Monocu.f, vol. 4, No. 2, at 38 (Spring 1961) (under the pseudonym "Charles Lund").

The White Citizen Considers a Fearful Possibility, Monocle, vol. 3, No. 7, at 22 (Summer 1959) (under the pseudonym "Charles Lund"). 
Incident, Muriny, vol. 2, No. 3, at 166 (Spring 1960), reprinted in C. Bl.ACK, Tel.scopts \& ISL.ANDS 28 (1963).

The Day After Christmas, The New Ori.eans Poftry Journal., vol. 4, No. 3, at 13 (undated), reprinted in C. Black, Tei.escopes \& Islands 14 (1963), and in C. Bl.ack, The. Waking PASSE:NGir 55 (1983).

Pizzale Michelangelo, The New Orl.eans Portry Journal, vol. 4, No. 3, at 14 (undated), reprinted in C. Bl.Ack, Tel.fscopes \& Islands 9 (1963), and in C. Black, The Waking PASSENGer 42 (1983).

a Cold Day, The: New Ort.eans Poetry Journal, vol. 4, No. 3, at 15 (undated).

The Vine, The: New Orlfans Poetry Journal, vol. 4, No. 3, at 15 (undated), reprinted in C. Bl.Ack, THI.kSCOPES \& Isl.ANDS 35 (1963).

Three Sounds From Everywhere, Thr Nrw Orleans Poetry Journal, vol. 4, No. 3, at 16 (undated).

Patio Legend, The. New Orlekans Poktry Journal, vol. 4, No. 3, at 16 (undated), reprinted in C. Bl.Ac:k, Trilescophs \& Isl.ands 47 (1963).

The Others, The New Ori.eans Poetry Journal, vol. 4, No. 3, at 17 (undated), reprinted in C. Bi.ack, Til.pscophs \& Islands 29 (1963), in C. Black, The Waking Passenger 51 (1983), and in 95 YALE. L.J. 1592 (1986).

Not It, The: New Orlekans Poktry Journal, vol. 4, No. 2, at 21 (May 1958).

Occam's Razor, The. Nkw Orl.ens Poetry Journal., vol. 4, No. 2, at 22 (May 1958).

Your Move, The New Orleans Portry Journal, vol. 4, No. 2, at 24 (May 1958).

The Other, Thi: Nrw Ori.fans Poktry Journal, vol. 4, No. 2, at 25 (May 1958), reprinted in C. Bt.Ack, Tri.fescopes \& Islands 27 (1963).

Dreadful Night, The Nkw Orleans Poetry Journal, vol. 4, No. 2, at 26 (May 1958).

The Giants, The Nkw Orleans Poetry Journal, vol. 4, No. 2, at 26 (May 1958).

The Flower Woman, The: New Ori.eans Poetry Journal, vol. 4, No. 2, at 28 (May 1958), reprinted in C. Black, The Waking Passenger 16 (1983), and in 95 Yale L.J. 1590 (1986).

Ice Woman, The New Orlenans Poktry Journal, vol. 4, No. 2, at 30 (May 1958), reprinted in C. Bi.ac:k, The: Waking Passenger 23 (1983).

Lost Friend, The Nrw Ori.fans Poftry Journal, vol. 3, No. 3, at 6 (Sept. 1957).

The Monster, The Nkw Orl.eans Poetry Journal, vol. 3, No. 3, at 7 (Sept. 1957).

Flight, The. Nkw Orl.eans Poktry Journal, vol. 3, No. 3, at 9 (Sept. 1957).

Real Estate Office, The Nkw Orleans Poetry Journal, vol. 3, No. 1, at 11 (Jan. 1957).

Skin Diving, The New Orleans Poetry Journal, vol. 3, No. 1, at 11 (Jan. 1957).

In the Beginning, The: New Orleans Poetry Journal, vol. 3, No. 1, at 12 (Jan. 1957).

Three Years Later, The: Nrw ORl.eans Poetry Journal, vol. 2, No. 3, at 1 (July 1956), reprinted in C. Bl.ack, Tri.fscopes \& Isl.ands 42 (1963), and in C. Black, The Waking PassenGER 32 (1983).

Conversation with a Shepherd, NEw Orleans Review, vol. 10, Nos. 2-3, at 99 (Summer/Fall 1983).

The Mineral Kingdom, New York Times, Oct. 10, 1966, at 40, col. 5.

When Zeus Nods, New York Times, May 14, 1966, at 30, col. 5.

The Pacific Sea, New York Times (date unknown).

Adaptation from the Sumerian, Nomad, No. 4, at 9 (Fall 1959). 
Charles L. Black, Jr.

Tracker Home, Nomad, No. 3, at 20 (Summer 1959), reprinted in C. Black, Telescopes \& IsI.ANDS 11 (1963).

Sympathetic Magic, OASIS, No. 4, at 30 (1971).

The Dusty Piano, OAsis, No. 4, at 30 (1971).

Subway, Onyssex, vol. 1, No. 4, at 12 (1959).

Frustration, Onyssey, vol. 1, No. 4, at 13 (1959).

The Thing an Italian is Not, Pawn Poems, No. 38, at "9" (unpaginated) (Summer 1971).

The Sidewalk Cafe, PAwn, No. 33, at 6 (Lent Term 1967).

Four O'Clock, PAwn, No. 33, at 7 (Lent Term 1967).

A Character, Prisspective, vol. 14, No. 3, at 160 (Spring 1966).

The Uncaught, Perspecorive, vol. 13, No. 1, at 54 (Autumn 1962).

Indelibility, Persprc:rive, vol. 13, No. 1, at 54 (Autumn 1962).

First Cosmology, Persprcirive, vol. 10, No. 1, at 40 (Autumn 1957/Winter 1958), reprinted in C. Bl.ACK, Thi.yscoprs \& Ist.ands 24 (1963).

Falseface Mythology, Poriry Norrhwesr, vol. 10, No. 1, at 40 (Spring 1969).

The Pretender and the Gorilla, Pokrry Northwest, vol. 10, No. 1, at 40 (Spring 1969).

The False Accusation, Pokiry Northwest, vol. 7, No. 1, at 8 (Spring 1966).

My Queen of the Blues, Poriry Northwest, vol. 7 No. 1, at 8 (Spring 1966), reprinted in C. Bi.ack, The: Waking: Passenger 71 (1983).

Mavis, THE: Qussr, vol. 3, No. 2, at 82 (Winter/Spring 1969).

A Late Mingling of Lauyers, THE. Quesr, vol. 3, No. 2, at 83 (Winter/Spring 1969).

The Utterly Forgotten Poet, ThE: Quesr, vol. 3, No. 2, at 84 (Winter/Spring 1969), reprinted in G. Bi.ac:k, OWis Bay in Babyion 29 (1980).

A Winter Predicate, Tht Qukst, vol. 3, No. 1, at 10 (Summer/Fall 1968), reprinted in C. BLACK, Owis BAy in Babyion 56 (1980).

The Light Wind, THE QuFsi, vol. 3, No. 1, at 11 (Summer/Fall 1968), reprinted in C. BLACK, OWIS BAY IN BABYI.ON 47 (1980).

Sabbath of the Heart, 29 Rurciks L. REv. 317 (Winter 1976), reprinted in C. Black, OwLS BAY IN BABYI.ON 12 (1980).

Unrecognizable Bodies, 29 Rưrckss L. REv. 317 (Winter 1976).

Gauguin Alive and Dead, Thr. Skwanef. Review, vol. 85, No. 3, at 431 (July-Sept. 1977), reprinted in C. Bi.ack, The: Waking Passenger 60 (1983).

Our Sorrowing Interval, Th: Skwanee Review, vol. 84, No. 3, at 397 (July-Sept. 1976), reprinted in C. Bi.ack, OWis BAy IN BABylon 3 (1980).

Performance, Shenandoah, vol. 8, No. 2, at 58 (Spring 1957).

Feat, Suncis of trhe OPEN RoAd, vol. 25, Spring Annual, at "30" (unpaginated).

The Criminal Romance, Sourrhern Humanities Review, vol. 10, No. 2, at 138 (Spring 1976), reprinted in C. BI.ACK, OWIS BAY IN BABYLON 23 (1980).

The Ruined House, Souritrin Humantries Review, vol. 10, No. 2, at 139 (Spring 1976).

The Rich Red-Headed Girl, SourhriRn Humanities Review, vol. 10, No. 2, at 139 (Spring 1976). The Way of Opportunity, Sourhren Humanities Review, vol. 8, No. 4, at 494 (Fall 1974).

Another Version of Herodotus, Sourhiern Humanities Review, vol. 8, No. 4, at 495 (Fall 1974).

The Foot of the World, Sourhern Humanities Review, vol. 8, No. 4, at 495 (Fall 1974), reprinted in C. Bi.acik, The Waking Passenger 53 (1983).

Coinage of the Sea, SoUthern Humanities Review, vol. 7, No. 1, at 34 (Winter 1973). 
Northeastern Forest, SOUTHERn Humanities RevieW, vol. 7, No. 1, at 34 (Winter 1973), reprinted in C. BLAcK, OWLS BAY IN BABYLON 52 (1980).

News of a Death Comes Comes to the Island, SOUtHeRn Humantries Review, vol. 7, No. 1, at 35 (Winter 1973).

Her Girlhood and Her Hair, Southern Humanitres Review, vol. 7, No. 1, at 35 (Winter 1973).

The Clockwinder, The Southern Review, vol. 18, No. 3, at 547 (July 1982).

The Prophet Without Honor, The Southern Review, vol. 14, No. 3, at 498 (July 1978), reprinted in C. Black, The Waking Passenger 58 (1983).

The Man of Order in Hope, The SoutHern Review, vol. 14, No. 3, at 499 (July 1978).

The Shouting of a Huge Belief, SouthwEst REVIEW, vol. 67, No. 2, at 178 (Spring 1982), reprinted in C. Bl.ACK, The Waking Passenger 33 (1983).

Circumstances Surrounding the Disappearance of a Freightcar, SOUTHWEST REviEw, vol. 65, No. 3, at 247 (Summer 1980).

The Throathearted Blues, SouTHWEST Review, vol. 62, No. 1, at 21 (Winter 1977), reprinted in C. BLACK, OWLS BAY IN BABYLON 36 (1980).

The Man Who Wears Everything, Southwest Review, vol. 60, No. 4, at 340 (Autumn 1975), reprinted in C. BLACK, OwLS BAY IN BABYLON 19 (1980).

My Shadows, Southwest Review, vol. 59, No. 3, at 253 (Summer 1974), reprinted in C. BLACK, OWLS BAY IN BABYLON 53 (1980).

The East Wind, Southwest Review, vol. 57, No. 1, at 15 (Winter 1972), reprinted in C. Brack, OWLS BAY IN BABYLON 1 (1980).

The Way Home, Southwest Review, vol. 53, No. 1, at 45 (Winter 1968), reprinted in C. Br.ACK, OWLS BAy IN BABYLON 57 (1980).

The Limit Approached, Southwest ReviEw, vol. 52, No. 2, at 176 (Spring 1967).

The Oni Converted to Buddhism, Southwest Review, vol. 48, No. 4, at 376 (Autumn 1963), reprinted in C. Black, The Waking Passenger 61 (1983).

Summer Story, Southwest Review, vol. 46, No. 4, at 279 (Autumn 1961), reprinted in C. Black, The Waking Passenger 26 (1983).

Gulf Town, Southwest Review, vol. 44, No. 3, at 264 (Summer 1959).

The Clutter Man, Southwest Review, vol. 43, No. 4, at 327 (Aug. 1958), reprinted in C. Black, Telescopes \& Islands 20 (1963).

Rapprochement, THE SPIDER'S WEB, vol. 34, No. 1, at 24 (Spring 1968).

Clouds Over East Anglia, THE SPIDER's WEB, vol. 34, No. 1, at 25 (Spring 1968), reprinted in C. Black, OwLS Bay in Babylon 46 (1980).

Thanksgiving with David, THE SPIDER's WEB, vol. 32, No. 2, at 38 (Winter 1966), reprinted in C. Black, OwLS BAy in Babylon 27 (1980).

Day's End at the Carbarn, THE SPIDER's WEB, vol. 32, No. 1, at 56 (Fall 1965).

The Critic, THE SPIDER's WeB, vol. 32, No. 1, at 57 (Fall 1965).

Luck the Ladylight, SuRvivor, at 17 (undated, sometime in 1978).

Animal Experiments, Talisman, No. 12, at 18 (Winter 1957/Spring 1958).

Utility, Talisman, No. 12, at 18 (Winter 1957/Spring 1958).

The Madeleine, The Texas Observer, Oct. 14, 1983, at 21.

The Stone Girl, The TeXas Onserver, Oct. 14, 1983, at 21.

A Search, The TeXas Observer, Oct. 14, 1983, at 21.

The Proposed Pilgrimage, The TeXas Observer, Oct. 14, 1983, at 21.

Candle Patterns in Iceland, 31 ÚLfuJótur 338 (1978) (Icelandic Law Review). 
Charles L. Black, Jr.

Vatnajökull, 31 Úl.Fı jơrur 338 (1978) (Icelandic Law Review).

The Wind and the Ocean, The University (of Kansas CrTy) Review, vol. 36, No. 4, at 291 (Summer 1970).

Marionette Master, The University (of Kansas City) Review, vol. 31, No. 1, at 12 (Autumn 1964).

Floating Voices, The: Univirsitry (OF Kansas City) Review, vol. 29, No. 3, at 185 (Spring 1963), reprinted in C. Bi.ack, Th: Waking Passenger 25 (1983).

Bewitched Arcadia, The: Universrry (OF Kansas CrTy) Review, vol. 27, No. 3, at 233 (Spring 1961), reprinted in C. Black, Tel.escopes \& Islands 15 (1963).

Song in Summer, The Univirstry (of Kansas CrTy) Review, vol. 25, No. 4, at 301 (Summer 1959), reprinted in C. Biack, Telescopes \& IsLANDS 35 (1963).

Private Statuary, Votces, No. 178, at 10 (May-Aug. 1962).

Binary, Volces, No. 178, at 10 (May-Aug. 1962).

Botany, Whristont, vol. 4, No. 3 (old series), vol. 1, No. 1 (new series), at 111 (1964).

Time Past, Whe:ssrone, vol. 4, No. 3 (old series), vol. 1, No. 1 (new series), at 112 (1964).

Two Train Trips, Whersrone, vol. 3, No. 3, at 128 (1959).

The Second Stair, Whersronf, vol. 3, No. 3, at 129 (1959).

Things to Come, Whrisronk, vol. 3, No. 3, at 129 (1959).

Neo-Nazis in a Salzburg Beer Joint, Wherstone, vol. 3, No. 3, at 129 (1959).

Metamorph, Whr:rstone, vol. 3, No. 3, at 130 (1959).

Old Records, Wisconsin REvikw, vol. 9, No. 3, at 62 (undated; circa 1975).

Stickfigures, Wisc:onsin Revirw, vol. 9, No. 3, at 62 (undated; circa 1975).

End of Summer, Wwhimsy, vol. 2, No. 3, at "4" (unpaginated) (Dec. 1956).

The kind, Windfal.1. Porms, 1977, at "2" (unpaginated).

Untitled ("Give me a halter or a knife"), in Eckhardt, The Miscellanist, 95 YALE L.J. 1555, 1557 (1986).

The Tide Turns at Menemsha Bight, in Greenberg, Charles L. Black, Jr., 95 YALE L.J. 1559, 1560 (1986).

Letting Go, 95 Yat.t. L.J. 1592 (1986), originally published in C. Black, The Waking Passenger 12 (1983).

The Ones Who Died Young, 95 YAl.E L.J. 1593 (1986).

Two Romances, Yal.: LtThrary Magazine, vol. 129, No. 1, at 25 (May 1960), reprinted in C. Bi.Ac:K, THi.ESCol'HS \& ISI.ANDS 30 (1963).

The Fountains, Yal.k. Lithrary Magazinf, vol. 129, No. 1, at 26 (May 1960), reprinted in C. Bi.AC:K, Thi.HSCOPES \& Ist.ANDS 18 (1963).

Early Dark, Yat.f: LrTkRary Magazine, vol. 12, Nos. 4-5, at 213 (Mar. 1960), reprinted in C. Bi.AC:k, Tri.kscopks \& Ist.ANDS 34 (1963).

Minor Master, Yal.f. LITERARy Magazine, vol. 12, Nos. 4-5, at 213 (Mar. 1960).

Frozen Moon Shaman, Yai.z: Literary Magazine, vol. 12, Nos. 4-5, at 214 (Mar. 1960).

Blest of the Island, YAl.E LrTERARy MAGazine, vol. 12, Nos. 4-5, at 216 (Mar. 1960), reprinted in C. Bi.Ac:K, THi.kSCOPHS \& ISI.ANDS 10 (1963).

Mr White Horse, Thr: Yal.z. Rrvur, vol. 2, No. 7, at 13 (May 1975). 
